\title{
Patent Pools: Intellectual Property Rights and Competition
}

\author{
Victor Rodriguez ${ }^{*}$
}

TNO Innovation Policy Group, Wassenaarseweg 56, 2333 AL Leiden, The Netherlands

\begin{abstract}
Patent pools do not correct all problems associated with patent thickets. In this respect, patent pools might not stop the outsider problem from striking pools. Moreover, patent pools can be expensive to negotiate, can exclude patent holders with smaller numbers of patents or enable a group of major players to form a cartel that excludes new competitors. For all the above reasons, patent pools are subject to regulatory clearance because they could result in a monopoly. The aim of this article is to present the relationship between patents and competition in a broad context.
\end{abstract}

Keywords: Competition policy, European antitrust, patents.

\section{INTRODUCTION}

As the quantity of patents has increased, patent thickets (i.e. multiple upstream patents, where overlapping rights may impede the commercialisation of a product or process) have emerged, blocking innovation by others. In order to accommodate this, patent pools have been established [1,2].

A patent pool is an agreement between two or more patent owners to licence one or more of their patents to one another, or to licence them as a package to third parties [3]. Patent pools create useable bundles that overcome the 'tragedy of the anti-commons' while preserving the incentives to innovate. These co-operative arrangements allow the holders of several patents, all of which are necessary for the development of a product or process, to licence or assign their rights at a single price. Patent pools already have a history of helping technological and product development when rights are splintered. Further, patent pools also reduce licence transaction costs, distribute risks among the members of the pool and foster better exchange of information [4].

However, patent pools do not correct all problems associated with patent thickets. And there's nothing to stop the 'outsider problem' from striking pools, if members of a pool see a more lucrative route, they can simply step out and block the collective endeavour [5]. Moreover, patent pools can be expensive to negotiate, can exclude patent holders with smaller numbers of patents or enable a group of major players to form a cartel that excludes new competitors [6].

In particular, Lerner and Tirole [7] have built a tractable model which provides the following insights. First, a pool is more likely to be welfare-enhancing if patents are more complementary. That the demand margin binds in the absence of pool is a sufficient, but not a necessary, condition for a pool to be welfare-enhancing. Second, a pool is never affected by the possibility of independent licencing if and only if the pool is welfare-enhancing. Furthermore, with only

*Address correspondence to this author at the TNO Innovation Policy Group, Wassenaarseweg 56, 2333 AL Leiden, The Netherlands;

E-mail: victor.rodriguez@tno.nl two patents, independent licencing always yields the same outcome as in the absence of a pool if the pool is welfaredecreasing in the absence of independent licences. With more than two patents and a welfare-decreasing pool, there exists an independent-licencing equilibrium with the same outcome as in the absence of a pool. Third, the results generalise to a setting where the patents vary in importance. Furthermore, when one patent is dominant (so that the other patents cannot be used without it), a patent pool unambiguously boosts welfare. Fourth, when pool members are also downstream users, two additional concerns may emerge: pool members may be reluctant to create competitors by licencing to third parties, and licensors may seek to raise each others' cost by charging royalties. Regarding the first possibility, the results can be generalised as long as licencing contracts takes the form of fixed fees and the licenced technology reduces downstream users' fixed costs. In a setting where there are no third-party licencees, if royalties are not allowed, welfare may be harmed as otherwise-desirable pools are discouraged from being formed. Fifth, allowing a pool encourages innovation. Determining the impact on ex ante social welfare, however, is likely to be much more difficult. But allowing a pool with independent licencing never reduces and may increase ex ante welfare.

In this context, there is a need for the proper balance between the patent-related contracts and their impact on competition. The several uses of patents have been watched by competition authorities. Patent licences can be used for sharing markets by the inclusion of territorial exclusivity, or fixing prices even indirectly. Cross-licences can be regarded as tools for collusion and as barriers to entry. Patent pools are subject to regulatory clearance because they could result in a monopoly. The multiplicity of patents over a single area, with royalty-stacking, can cost so much that it might hamper innovation. The large number of patent holders might result in the tragedy of anti-commons, chronic under-use of patented resources.

The aim of this article is to present the relationship between patents and competition to keep a sense of perspective about what has been done scholarly. The 
remainder of this study is organised as follows. To begin with, the methodology is described. Next, the problématique is addressed. In turn, what is known, what is new and what remains to be learned are presented.

\section{METHODOLOGY}

A review of previous academic and policy-making documents have been conducted. For academic publications, Thomson Scientific's Web of Science, Elsevier's Scopus and Google Scholar have been used as search engines in order to retrieve state-of-the-art literature. For policy-making documents, Eur-lex has been employed, which provides online access to the EU official journal, treaties, legislation in force, preparatory acts, case law, and documents of the European Parliament, Council and Commission.

Further, the literature review addressed the research questions listed below. In addition, relevant references have been searched and then sorted them out into a coherent view of the state of the art as it now stands. In particular, a structure dealing with the research questions has been followed while carrying out the literature review:

1. Problématique: What is the issue at stake here? Why is it relevant? Why are we discussing this in the first place?

2. What is already known: What is the knowledge we are building upon? What has already been established? What is the current 'state of the art' in the topic?

3. What is new: What are the recent developments? What is currently being debated? What have we learned from the references? Which are the points of contention and their implications?

4. What remains to be learned: What are the future avenues of research or debate? What are the "blind spots' that still need to be tackled? Where is the topic or issue headed? Is there a need either for policy options or fields that require policy actions? Are the major issues studied in the project falling out of the mainstream legislative process?

Particularly, the following tasks have been carried out to achieve the overall aim:

- Retrieved references.

- $\quad$ Reviewed selected publications.

- $\quad$ Digested and distilled content.

- Drafted the review and provided policy recommendations.

- Validated findings and suggestions by relevant stakeholders.

\section{Problématique}

Innovators are motivated by high-expected profits, which are higher with a monopolistic position. On the other hand, companies in a situation of solid monopolistic position tend not to be motivated to innovate, as that would not significantly increase their already substantial profit margin. The threat or reality of competition forces incumbents to innovate, while for newcomers innovation is their ticket to enter the market [8].

A patent is the right to exclude competitors. A patent has direct anti-competitive effects as a product will have a higher price if it embodies a patented technology due to market power conferred by the patent. Nonetheless, competition will be induced by follow-up inventions in a dynamic process. In fast-moving technological areas, the monopoly position possibly provided by successful innovation is only temporary as new inventions arrive quickly, with superior technology taking over the market and leapfrogging incumbents. In this cycle, patents play the role of strengthening the market power that accrues to the successful inventor, hence reinforcing the incentive to innovate ex ante, but possibly weakening the incentive to innovate for the winner, at least ex post [9].

According to Duxbury and Tuck, a more recent factor affecting pharmaceutical companies' patenting and protection strategies is the European Commission's stance on antitrust law in an intellectual property context. The AstraZeneca decision (Commission Decision of 2005: Case COMP/37.507: Generics/AstraZeneca) together with the Commission's continuing sector inquiry have left the industry facing a great deal of uncertainty over what it will be permissible for a company to carry out in its intellectual property and commercial strategy, particularly when in a dominant position. The Commission's definition of the market in the AstraZeneca case seems to unfairly penalise the innovative company by creating a structure where the innovator that is the first to market a new class of drugs will inevitably be in a dominant position [10].

The preliminary results of the sector inquiry [11] show that market entry of generic companies and the development of new and more affordable medicines is sometimes blocked or delayed, at significant cost to healthcare systems, consumers and taxpayers. Citing a sample of medicines that faced patent expiration in the period 2000 to 2007 in 17 Member States, the European Commission report suggested that additional savings of around $€ 3$ billion would have been possible on that sample over this period if generic medicines had entered the market without delay. For the same samples over the said period total savings gained by generic entry amounted to at least $€ 14$ billion, the report added. Defining originator companies as the ones that develop and sell new medicines, the report found that these companies used a variety of methods to delay or block the market entry of not only generic companies but also other originator competitors. On the practices that the originator drug companies use to delay or block market entry of competing medicines, the European Commission listed among others: multiple patent applications for the same medicine (so called patent clusters,) initiation of disputes and litigation, conclusion of patent settlements which constrain market entry of generic companies and interventions before national authorities when generic companies ask for regulatory approvals [12]. 


\section{What is Already Known?}

As far as the legal architecture is concerned, the antitrust area covers two prohibition rules set out in the Treaty establishing the European Community (EC Treaty). First, agreements between two or more firms which restrict competition are prohibited by Article 81 of the EC Treaty, subject to some limited exceptions. Second, firms in a dominant position may not abuse that position (Article 82 of the EC Treaty). The European Commission is empowered by the EC Treaty to apply these prohibition rules and enjoys a number of investigative powers to that end (e.g. inspection in business and non-business premises, written requests for information etc). It may also impose fines on undertakings which violate EU antitrust rules. All national competition authorities are also empowered to apply fully the provisions of the EC Treaty in order to ensure that competition is not distorted or restricted. National courts may also apply these prohibitions so as to protect the individual rights conferred to citizens by the EC Treaty. "Articles 81 and 82 are now Articles 101 and 102 in the consolidated version of the treaty on the functioning of the European union".

From the perspective of economics, there is a direct relationship between the sales of innovative products and market structure and, implicitly, the average size of firms in a specific branch. According to the product life cycle, there are many small firms that compete in the first stages of technological development on design, and on combinations of product and market. In this situation, the market structure manifests a low seller concentration. Later in the cycle, when a specific combination of product and market dominates technological development, and when consumers are more inclined towards a particular design, firms have to abandon their unsuccessful product-market combinations in favour of a more successful competing design. Once a dominant design has been established, firms will start to compete on price and economies of scale become an important determinant in order to survive, which can lead to the start of an oligopolistic shake-out.

Many firms that fail to achieve a minimum efficient production scale must sooner or later leave the market, which results in a market dominated by a few large firms competing on price [13]. Nevertheless, firms facing Bertrand competition possess a strong incentive to increase their profit margin through product differentiation, and will therefore reap more sales from new products if their products succeed in time [14]. Small firms, in turn, possess a strong incentive to introduce new products into the market in order to survive competition with current firms. Large firms have an incentive to invest in both process (economies of scale) and product innovation (economies of scope) in order to maintain their market position [15]. Finally, Aghion et al. [16] show that an inverted $\mathrm{U}$-shaped relationship between competition and innovation is a good fit, which challenges both empirical and theoretical findings in the traditional literature.

A patent rewards an invention, a new technology, which sometimes results in creating a new market. In that case, the effect of patents from the time period without the protected invention to the time period with the protected invention is not to restrict competition on markets already existing in the previous period of time, but to create a new market (possibly monopolised, but still better than no market at all). Second, patents offer a substitute to secrecy and involve disclosure, hence they encourage further innovation (i.e. competition of new products against existing ones). Third, patents can serve the creation of new companies by protecting them from competitive strategies based on incumbency, such as size, brand or sunk costs.

Firms tend to patent more of their inventions when they are confronted with more intense competition. Weaker competition, due to regulation or high-entry cost, provides protection other than intellectual property rights (IPRs) to the innovations of the incumbents, which then have little reason to incur the cost of filing IPRs and disclosing their technology. However, as patents in turn reduce ex post the degree of competition on a market, it is difficult to observe correlation between patenting and competition at the market equilibrium.

\section{What is New?}

In knowledge-intensive industries, competition is based less on prices and current market share and more on new products and technologies and future market share. The market power criterion is more fragile as the state of play can be reshuffled by new technologies. Substitute products are not the current competitors but the ones that will be on the market in the future [17].

In particular, Reitzig [18] shows that multiple patents per invention are filed in both discrete and complex technologies. In selected discrete technologies, patent fences may serve to exclude competitors whereas in complex technologies, patent thickets represent exchange forums for complementary technology. The results expand on traditional views of profitable patent exploitation across industries, which suggest that different legislative issues arise from multiple patenting per innovation in complex and discrete technologies depending on the degree of technological complementarity. The results have unexpected policy implications in that they illustrate how patentees could eliminate competition in the form of substitute technologies through fencing.

In one case of the European Commission pharmaceutical sector inquiry, $1300 \mathrm{EU}$-wide patents (patent clusters) were filed for a single medicine. The inquiry pointed out that nearly 700 cases of reported patent litigation with generic companies were filed. Although the generic companies won some of these cases, there were many settlement agreements for ending an ongoing litigation or dispute. These specific settlements limited the entry to the market of the generic medicines and provided for payments from the originator to the generic companies. Moreover, the report found strangulation of innovation, as some originator companies used defensive patenting strategies thus obstructing the path of innovation from competing pharmaceutical companies, imposing a final delay to consumers' access to innovative medicines. 
Further, Roox et al. [19] depict the key areas in which the patent system and the legal and regulatory framework fail to ensure an appropriate balance between incentives and competition, such as failings in the system for granting quality patents, patent thickets and follow-up patents, patent litigation procedures and other patent-related barriers. First of all, failings in the system for granting quality patents comprise a lack of rigorous assessment of the patentability requirements, in particular of the inventive step, lack of quality of applications, examiners' inability to check data presented to them, not enough consideration of third-party observation by examiners and weaknesses in the opposition procedure. Second, patent thickets and follow-up patents encompass unjustifiable extension of the monopoly by follow-up patents, multiple divisional patent applications that are entirely identical to the parent specifying data without linking it to the claims, second and subsequent use claims, and genuine incremental innovation compared to simple changes. Third, patent litigation procedures include the complexity and unpredictability of litigation across the EU and improper granting of interim injunctions, Finally, other patent-related barriers cover patent linkage, statements to authorities, shifting consumer demand with marketing campaigns, supplementary protection certificates granted on the basis of incorrect information.

\section{What Remains to be Learned?}

Patents can be used in anti-competitive strategies, whose aim is to exclude other companies (competitors) from the market. In that context, patents are not just means to exclude competitors, they are instruments used by incumbent firms to raise entry barriers. Patents are also used by new entrants to penetrate markets. Patents are used in standard-setting processes and for making alliances. This diversified role of patents renders their effect on competition more complex. Some anti-competitive strategies are clearly illegal, others are abuses of the system, permitting an undue extension of the exclusive right beyond the one granted by the patent office. These practices can be deterred, and often are, by a close monitoring by competition authorities. A question raised to patent offices is to what extent could such practices be hampered upstream, by granting patents which would not facilitate, or would even hamper them? Could patent law and practice tackle some of these problems?

Pharmaceutical companies enjoy patent protection for their products. Once the patent has expired, producers of similar generic products can enter the market. Pharmaceutical companies that try to prolong patent protection for a product may breach EU competition rules. Such behaviour can also have the side effect of removing incentives to innovate as competition from generic products encourages the creation of new products. In this respect, AstraZeneca was deemed to abused the patent system and the system for authorisation of medicines with the aim of delaying competition to a blockbuster drug from generic and parallel imported pharmaceuticals. AstraZeneca was fined $€ 60$ million. The appeal is currently pending before the Court of First Instance. As a result of this first case, the Commission intensified the monitoring of competition in the sector of generic medicines. The first findings indicate that competition in the market for human medicines may not be working well in Europe; fewer new medicines are being brought to market and the entry of generic medicines sometimes seems to be delayed. The Commission has therefore opened a sector inquiry to investigate the reasons for this [20].

The financial institutions have devised various tools for patent holders to obtain monetary value from their patents more promptly than collecting royalties from licences. These mechanisms include securitisation based on anticipated royalty income streams, auction of patents, patent collateralisation, patent sale-lease-back arrangement, and patent litigation insurance. The European Commission opened formal proceedings in January 2009 after complaints were lodged in July 2008 because of non-requested services. Standard \& Poor's is the only issuer of valid identifying numbers of American bonds or stocks. Without these unique numbers, securities cannot be exchanged, according to international agreements aimed at avoiding duplication and potential loss of assets. According to plaintiffs, Standard \& Poor's is thus benefiting from its monopoly by imposing charges not only on providers of financial data such as Bloomberg and Thomson Reuters, but also by charging financial institutions directly. The potential new charge follows a wide-ranging review of rules governing credit rating agencies' activities launched by the Commission in November 2008. Internal Market Commissioner Charlie McCreevy has chosen to highlight the responsibilities of rating agencies on several occasions during the ongoing financial crisis. The agencies stand accused of setting excessively high credit rates, which later turned insolvent [21].

In one of the scenarios on how might intellectual property regimes evolve by 2025 , patent pools are brought into account. In the setting called 'Blue Skies', a globally positive attitude to technology has led to flourishing healthcare R\&D. Pharmaceutical companies still rely on patents, albeit with restrictions that ensure research exemptions and access for poorer nations. Areas such as genetic diagnostics have adopted a system of licencing, patent pools and clearinghouses to ensure optimal use of available technologies. But major breakthroughs come from a thriving information and communication technology sector that enables new forms of disease prevention by combining sophisticated diagnostics, advice and the control of human behaviour using technology. Epidemiological, pharmaceutical and genetic research is helped by huge interconnected databases bringing genomic, clinical, familial and social data together on a worldwide scale. Ethical objections to biotechnology have made way for 'utilitarian' cost-benefit appraisal: stem-cell treatments, advanced prosthetics and embryo screening are accepted. The first attempts at genetic enhancement are supported in large parts of society.

Finally, complements to competition and patents are open source, open science, open access, open innovation and open standards. Open source projects are based on collaborative innovation and are characterised by a non- 
proprietary setting. Open science offers free collaboration and rapid public disclosure of results with no restrictions on use other than acknowledging the source. Open access provides users free reading, downloading, copying, distributing, printing, searching or linking. Open innovation prioritises partnering, licencing and venturing to combine internal and external sources of ideas and technologies. Open standards are publicly available specifications which give a common method of achieving a particular goal.

\section{REFERENCES}

[1] Merges R. Institutions for intellectual property transactions: The case for patent pools. Available from: http://www.law.berkeley. edu/instit utes/bclt/pubs/merges/pools.pdf [Accessed: April 2009].

[2] Shapiro C. Navigating the patent thicket. Available from: http://faculty.haas.berke ley.edu/shapiro/thicket.pdf [Accessed: April 2009].

[3] Overwalle G, Zimmeren E, Verbeure B, Matthijs G. Models for facilitating access to patents on genetic inventions. Nat Rev Genet 2006; 7: 143-54.

[4] Clark J. Patent pools: a solution to the problem of access in biotechnology patents? Available from: www.uspto.gov/web/ offices/pac/dapp/opla/ patentpool.pdf [Accessed: April 2009].

[5] Bessen J. Patent thickets: Strategic patenting of complex technologies. Available from: http://www.researchoninnovation.org/thicket.pdf [Accessed: April 2009].

[6] European Patent Office. Scenarios for the future. Available from: $\mathrm{http} / / / \mathrm{www}$.epo.org/focus/patent-system/scenarios-for-the-future. $\mathrm{html}$ [Accessed: April 2009].

[7] Lerner J, Tirole J. Efficient patent pools. Am Econ Rev 2004; 94 : 691-711.

[8] Encaoua D, Ulph D. Catching-up or leapfrogging? The effects of competition on innovation and growth. Cahiers de la Maison des Sciences Economiques. Paris: Université Panthéon-Sorbonne 2000.
[9] Guellec D, van Pottelsberghe B, van Zeebruck N. Patent as a market instrument. In: Guellec D, van Pottelsberghe B, Eds. The economics of the European patent system: IP policy for innovation and competition. Oxford: Oxford University Press 2007.

[10] Wragge and Co. Pharmaceutical patents need a new lease of life. Managing Intellectual Property, December 2008 and January 2009.

[11] European Commission. Pharmaceutical sector inquiry: Preliminary report. DG Competition Staff Working Paper. Brussels: European Commission 2008.

[12] Singh T. A bitter pill of sector inquiry for the drug business. New Europe 16, 810 (30 November-6 December) 2008; p. 38.

[13] Klepper S. Entry, exit, growth, and innovation over the product life cycle. Am Econ Rev 1996; 86: 562-83.

[14] Kaniovski S. Product differentiation and competitive selection. J Evol Econ 2005; 15: 567-80.

[15] Cohen W, Klepper S. Firm size and the nature of innovation within industries: The case of process and product R\&D. Rev Econ Stat 1996; 78: 232-43.

[16] Aghion P, Bloom N, Blundell R, Griffith R, Howitt P. Competition and innovation: an inverted-U relationship. Quart J Econ 2005; 120: 701-28

[17] Encaoua D, Hollander A. Price discrimination, competition and quality selection. Cahiers de la Maison des Sciences Economiques. Paris: Université Panthéon-Sorbonne 2004.

[18] Reitzig M. The private values of 'thickets' and 'fences': towards an updated picture of the use of patents across industries. Econ Innov New Technol 2004; 13: 457-76.

[19] Roox K, Pike J, Brown A, Becker S. Patent-related barriers to market entry for generic medicines in the European Union: a review of weaknesses in the current European Patent System and their impact on the market access of generic medicines. Brussels: European Generic Medicines Association 2008.

[20] European Commission DG Competition, Pharmaceutical sector overview. Available from: http://ec.europa.eu/competition/sectors/ pharmaceuticals/ overview_en.html [Accessed: April 2009].

[21] EurActiv. Standard \& Poor's hit by EU antitrust probe. Available from: http://www.euractiv.com/en/financial-services/standard-poorhit-eu-a ntitrust-probe/article-178447 [Accessed: April 2009].

(C) Victor Rodriguez; Licensee Bentham Open.

This is an open access article licensed under the terms of the Creative Commons Attribution Non-Commercial License (http:/creativecommons.org/licenses/by-nc/ 3.0/) which permits unrestricted, non-commercial use, distribution and reproduction in any medium, provided the work is properly cited. 